AIDS

\section{More money promised}

\section{Washington}

RESPONDING to charges that the government has neglected acquired immune deficiency syndrome (AIDS), a disease that so far has primarily afflicted male homosexuals and drug addicts, the US Public Health Service (PHS) last week declared AIDS its "number one priority". Dr Edward Brandt, the assistant secretary for health, said PHS would spend \$14.5 million on AIDS research and epidemiological investigations this year, almost as much as has been spent on legionnaire's disease in the entire seven years since that disease was discovered.

PHS, which includes the Centers for Disease Control (CDC) and the National Institutes of Health, has felt increasing pressure to step up work on AIDS from homosexual groups, Congress and more recently - amid reports that AIDS may be spread by blood transfusions - haemophiliacs and others dependent on frequent transfusions.

In making the announcement, Brandt specifically denied that AIDS had been neglected, as some have charged, because it strikes mainly homosexuals. Of the 1,450 cases reported since June 1981, 71 per cent have been in male homosexuals and bisexuals.

Several members of Congress, who called the announcement too little too late, are seeking to boost the PHS budget. Senator Lowell Weicker (Republican, Connecticut) was preparing last week to introduce an amendment to the 1983 supplemental budget - funds that would be made available immediately - that would commit $\$ 12$ million specifically for AIDS research. And the House of Representatives Energy and Commerce Committee has already reported out a bill sponsored by Representative Henry Waxman (Democrat, California) that would create a $\$ 30$ million fund for public health emergencies beginning in fiscal year 1984. Although this bill does not specifically address AIDS, it is understood that AIDS would immediately qualify as an "emergency" under the bill. (Waxman's bill is HR 2713; the counterpart measure in the Senate, filed by Senator Alan Cranston (Democrat, California) is S 1226).

Brandt emphasized last week that there is no cause for panic about AIDS in the general population; indeed, the entire announcement may have been more an effort to assuage worries than a reflection of a genuinely new policy. Apart from using the occasion to announce the award of six research grants for AIDS studies and the Food and Drug Administration's approval of a new heat treatment for blood products (actually of uncertain utility in preventing transmission of AIDS since the infectious agent is unknown), Brandt gave no indication of what would happen as a

\section{Plant disease}

result of the "number one priority" designation that is not already happening.

An aide to Senator Cranston said that most of the $\$ 14.5$ million would be diverted from other programmes at CDC. Congress appropriated only $\$ 2$ million for CDC's AIDS investigation this year, and \$1 million of that was intended to replace funds that had been diverted in past years to AIDS from other areas, mainly venereal

diseases and hepatitis. Both Cranston and Waxman blame the administration for not requesting more funds.

The latest data from $\mathrm{CDC}$, presented last week, underscore the concern about the disease. The fatality rate among those diagnosed two years ago or earlier is 82 per cent; overall, the fatality rate is 38 per cent. Besides male homosexuals, the high risk groups are users of injectable drugs (17 per cent of the reported cases), recent Haitian immigrants to the United States (5 per cent) and haemophiliacs (1 per cent).

Stephen Budiansky

\title{
Italy's farmers battle with virus
}

BUREAUCRATIC indecision hamstrings the battle of Italian growers and agricultural scientists against an infestation of plum pox virus, a serious disease of the plum and the apricot, in the regions around Turin and Bologna. The disease could do considerable damage to Italian exports.

Plum pox appears to have come in with root stock from endemically infested Yugoslavia, and so far affects only apricots. It might have been halted in Italy this year if only the infected trees had been destroyed before the aphids flew this spring, but the regional authorities that would have to compensate farmers for the loss of their trees have yet to decide on the principle, let alone the amount of compensation, so farmers are understandably somewhat reluctant to destroy their orchards.

In Turin, the Piedmont regional government has, however, taken the small step of agreeing to pay for a student to work two days a week collecting samples from potentially affected trees, so monitoring the spread of the disease. In Bologna, the disease is said to have a strong grip but to be even less well controlled than in Turin.

Dr Maurizio Conti, who leads a group dealing with plum pox at Italy's leading applied plant virology research institute in Turin, is openly critical of the Piedmont authorities. He claims that they are spending their money in the wrong way. Conti's group detected the outbreak, and warned the authorities, as long ago as last August. But still there is no compensation agreement and so no proper control.

This year, in Piedmont, the spread of the disease has been slowed only by the publicmindedness of one grower, whose orchard of 200 or so trees was 60 per cent affected, the worst in the region. He destroyed them all, without promise of compensation. But there are twelve other foci of infection around Turin where the infected trees still stand.

Conti hopes that the outbreak can nevertheless eventually be contained. In laboratory experiments, he has found that aphids transmit the disease only slowly. With the aid of the student provided by Piedmont, and using an enzyme-linked immunoassay system (ELISA) to identify the virus, he is tracking the spread of the virus.

But Conti is running short of the antiserum that the ELISA technique needs, and has not yet had time to develop a labor. atory method of producing it. Moreover, there is a sampling problem. Virus infection is often localized to, say, a single branch of a tree, so that the use of ELISA is confined to confirming a diagnosis on visibly affected branches.

If the disease does establish itself in Italy, the chief consequence will be that the

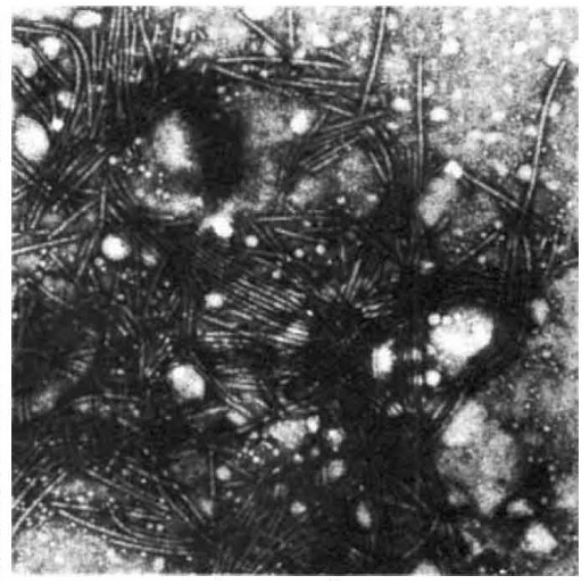

The offending plum pox virus

export of root stocks will be inhibited. Plum yields will also fall, although not disastrously. In Britain, where one in five of plum orchards is to some degree affected, the fruits of varieties such as the Victoria plum are corrupted while other varieties suffer a loss in yield of 10-20 per cent. In Britain, the disease is contained by close monitoring and grubbing out infected stock.

In Italy, links between farmers and researchers are weaker. Conti says that agricultural ailments tend to be regarded as acts of God. The national plant protection service is mainly concerned with monitoring imported stocks, plainly without success in keeping out plum pox. Conti wants some regular system for demonstrating to farmers the effects of plant diseases so that self-monitoring will be practicable.

Robert Walgate 